\title{
AR 技術を用いた配管施エ支援システム
}

\author{
白石 耕一郎 ${ }^{* 1}$, 松尾 宏平 ${ }^{* 2}$ \\ Piping installation support system using augmented reality \\ Koichiro SHIRAISHI ${ }^{* 1}$ and Kohei MATSUO ${ }^{* 2}$ \\ ${ }^{* 1,{ }^{*}}$ National Maritime Research Institute, Japan \\ 6-38-1 Shinkawa, Mitaka-shi, Tokyo 181-0004, Japan \\ Received 30 November 2014

\begin{abstract}
In this paper, authors introduce an AR application which supports a pipe drawing work in a shop floor of a shipyard. Some pieces of pipes are not designed beforehand in ship design process, as they contain uncertainty caused by pipe production and assembly in a factory. These pipes are usually designed and fabricated individually in a shop floor by the method that is far from be digitalized. The piping work of gauging pipes takes an immense amount of time. Because those works are composed of 3 processes, measurement of relative position of both ends of flanges, design of the pipe and confirmation of the piping design. In order to reduce the time of those piping work, the authors have developed the AR application which can design the gaging pipes automatically. The AR application measures the location of both ends of the pipe using image processing, automatically draws a suitable shape of the pipe, and effectively illustrates graphics of the pipe as AR once the worker holds a tablet PC to the direction he wants to fix the pipe. The paper explains details of above AR applications, including those system diagrams, and shows some results of demonstration for easy understanding how they work.
\end{abstract}

Key words : Augmented reality, Piping installation, Shipbuilding, Automatic design

\section{1. 緒言}

船舶は，燃料，海水，そして圧縮空気等を船内のあらゆる場所に行き渡らせるため，何千本という配管が張り 巡らされている，配管を精確に施工することによって，効率が良く，トラブルの少ない船を実現できる．また， 配管の施工時間を短縮できれば，建造期間の短縮にもつながり，建造コストを抑えることも可能である。このよ うに造船工程において，配管施工は建造費用や運航性能を決める重要な作業のひとつである.

多くの商船は，ブロック建造法と呼ばれる方式で建造される．ブロック建造法とは，船体を幾つかのブロック に分割し，個々のブロックを予め地上で組み立て，出来上がったブロックを船台に運び上げ，それぞれを接合す る方法である。しかしながら，各ブロックの接合箇所の精度管理は非常に難しいため，設計段階では接合箇所の 詳細な配管設計は行わず，現場で配管の計測，設計，そして施工を行う場合が多い。この工程は「合わせ管」と 呼ばれ，熟練した技術が求められる(村上他, 2012). 一般商船では，数百本もの合わせ管が存在し，船内の艤装の 中でも時間を要する工程であるため，作業の高精度化及び効率化が求められている．合わせ管は，管をつなぐフ ランジ位置の計測，フランジ間をつなぐ配管設計，管製作，そして，製作した管の取り付けといった流れで行わ れる.

そこで, 著者らは「合わせ管」の工程を簡易化し, 効率良く施工できるようにするために Augmented Reality(AR) 技術を用いた配管作業支援システムを開発している(Matsuo and Shiraishi, 2014) (白石, 松尾, 2014a) (白石，松尾，

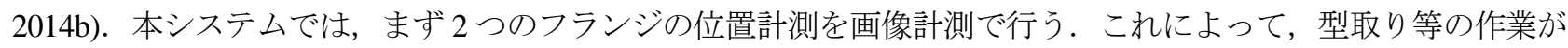

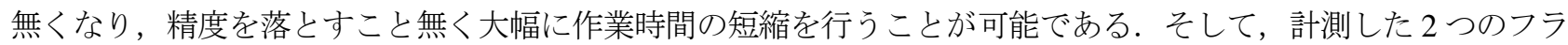

No.14-00648 [DOI:10.1299/transjsme.14-00648], J-STAGE Advance Publication date : 18 May, 2015

*1 国立研究開発法人 海上技術安全研究所（广181-0004 東京都三鷹市新川 6-38-1）

*2 正員，国立研究開発法人 海上技術安全研究所

E-mail of corresponding author: shiraishi@nmri.go.jp 
ンジ間をつなぐため配管設計を自動的に行うことが可能である. また, ARを用いることによって, 実際の現場 の風景に配管の設計案を投影することができ, より直感的に設計を確認することが可能である.

本論文では，まず著者らが開発した配管施工支援 AR システムの概要について説明し，実験室で行った精度検 証試験について報告する，そして，開発したシステムが実際の造船現場で有効であるかを確認するために，修繕 船内において検証実験を行ったので，その結果についても報告する．また，本実験によって明らかになった当該 システムの課題点についても考察を行う。最後に，本研究のまとめと開発したシステムの今後の展開について述 ベる.

\section{2. 配管施エ支援システム}

\section{$2 \cdot 1$ システムの概要}

著者らは現場合わせ管の工程を簡易化し，効率良く施工できるようにするために AR 技術を用いた配管作業支 援 AR システムを開発した。 このシステムの構成を図 1 に示す.

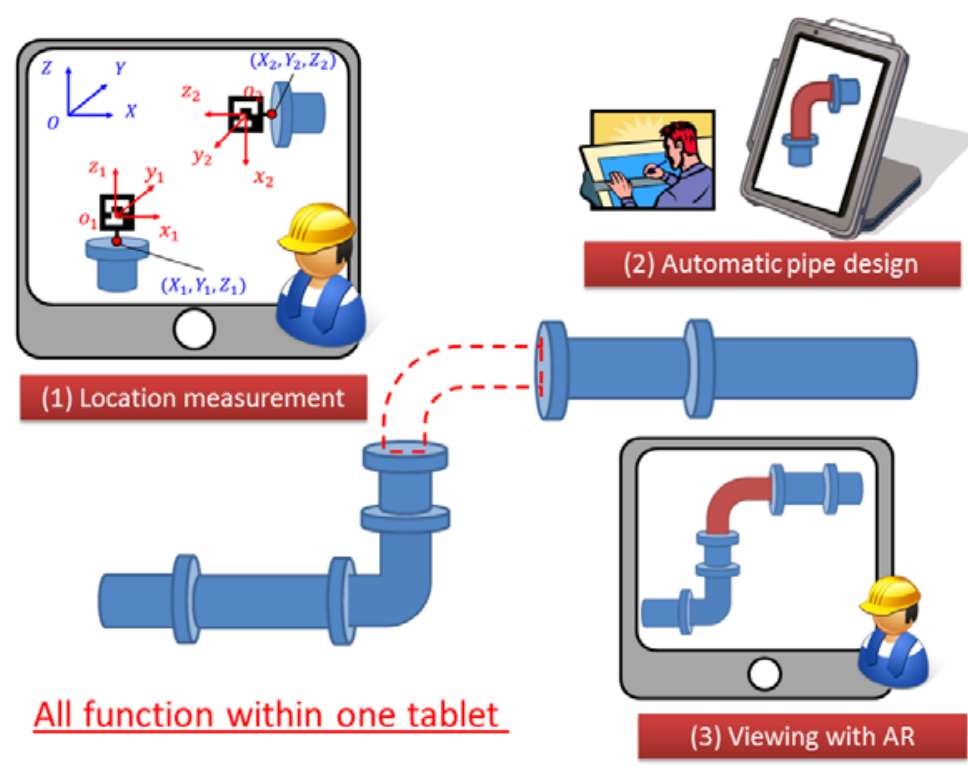

Fig.1 Concept of Piping Installation Support System Using AR

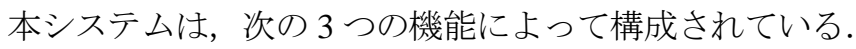

(1) 画像計測を用いた位置計測

(2) 自動配管設計

（3）ARによる配管設計案の表示

(1)の画像計測を用いた位置計測では画像計測技術を用いて, パイプを接続する 2 つのフランジの相対位置を計 測する. 具体的には, 図 1 の図中にもあるように，2つのフランジにマーカを取り付け，それぞれのマーカの方 向を計測する. 図 1 の左上図の $o_{1}-x_{1} y_{1} z_{1}$ と $o_{2}-x_{2} y_{2} z_{2}$ はそれぞれのマーカの座標系を示している. そして, 空 間座標系 $O-X Y Z$ において, それぞれのマーカの中心位置 $\left(X_{1}, Y_{1}, Z_{1}\right)$ と $\left(X_{2}, Y_{2}, Z_{2}\right)$ を計測し, それ結果から相対 位置を算出する．これらの位置計測は全て ARToolKit を用いることで実施することが可能である(加藤, 2002). ま た, ARによる位置計測によって型取り等の作業が無くなり, 精度を落とすこと無く大幅に作業時間の短縮を行 うことが可能である. (2)の自動配管設計では, (1)で計測したフランジの相対位置データを用いて, 両フランジを 接続するため配管設計を自動的に行う. (3)の設計案の表示では, AR を用いることによって, 実際の現場の風景 に配管の設計案を投影する. ARによって直感的に設計を確認することが可能である. 次節以降に配管施工支援 $\mathrm{AR}$ システムの各機能の詳細について説明する. 


\section{$2 \cdot 2$ 画像計測によるフランジの位置計測}

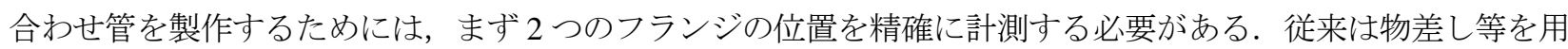
いて計測していたが，精度を確保するのが難しく，作業効率も悪いという問題があった．最近は，レーザースキ ヤナーなどの 3 次元計測器を用いる場合もあるが, 導入コストが高く, 設置場所が限られるという問題点がある. 本研究では, フランジにマーカを取り付け，そのマーカの位置を画像計測によって計測することによって， 2 つのフランジの相対位置を計測する．なお，画像計測は ARToolKit のライブラリを用いた(加藤, 2002). 具 体的には，2つのマーカの中心位置を画像処理で認識させ，その位置を用いて両フランジの相対位置を算出 する.

\section{$2 \cdot 3$ 自動配管設計}

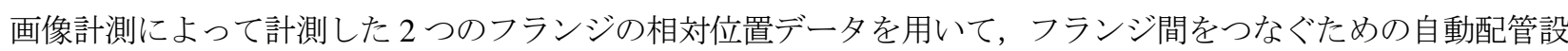
計を行う。本研究では, 自動配管設計ツールとして, 安藤らが開発しているプログラムを使用した(安藤, 木村, 2012) (Ando and Kimura, 2013). 設計対象空間を格子状に分割して重み付きグラフを生成する際，グラフのノード を特徵付ける状態量として, 格子分割した各格子の位置座標に加え, その格子を通るパイプの方向を考慮するも のである．これによって，パイプ直径に依存しない自由な寸法で配管設計が可能となる．また，直角に曲がるエ ルボだけでなく， S 字に曲がるようなベンドも考慮することが可能である．また，本プログラムは，障害物を自 動的に回避する機能も有している．障害物はポリゴンや直方体として入力寸ることが可能である．また，複数本 の配管設計を自動に行うことも可能である.

\section{$2 \cdot 4$ AR を用いた配管設計案表示}

前節で述べた自動配管設計機能で作成した設計案を ARによってタブレット上に表示する. これによって直感 的に設計を確認することが可能である．設計案の AR 表示についても ARtoolkit を使用しており，配管は OpenGL を用いて描画している.

\section{$2 \cdot 5$ 配管施工支援 $\mathrm{AR}$ システムの流れ}

本システムはタブレット上で使用することが可能である。したがって，タブレット上で現場合わせ管の位置計 測, 配管設計, 設計案の確認を全ての作業を行うことができるという特徴を持っている. また, 本システムは GUI 機能を備えており，ほとんどの操作をボタン操作(タッチパネル操作)のみで行うことができる. 配管施工支援シ ステムを用いて合わせ管を施工する流れを以下に示寸.

(1) 対象の現場合わせ管の両端となる相手側のフランジを確認する.

(2) この相手側フランジにマーカを取り付ける. (将来的には, 相手側フランジのボルト穴を使って, 留めるだ けでマーカをセットできる「マーカ付フランジ」の利用を想定する.）

（3）対象配管の前で，ARアプリケーションを起動する，そして，対象配管の基本情報（材料，呼び径，呼び圧 力等) を入力する.

(4) 両方の相手側フランジが 1 画面中に同時に見えるようにカメラをセットする.

（5）画像解析によるフランジ位置の自動計測，自動配管設計を行い，配管設計案を AR 表示する.

(6) 設計案の確認後，管製作，管の取り付けの工程を行う.

\section{$2 \cdot 6$ 検証試験}

配管施工支援 AR システムの有用性を検証するために，三次元空間の任意の 2 点にマーカを設置し，その 2 点 をつなぐ配管設計及び設計案の投影が可能かどうか検証するための実験を行った． Experiment 1 では 2 つのマ カの Z 座標が同じになるように設置し，Experiment 2 では Z 座標が異なるように設置した.

図 2 及び図 3 における左図がマーカの配置位置，右図が配管施工支援システムを用いて自動配管設計によって 設計された設計案を示している. 図 2 及び図 3 から分かるように，両方の実験設定において，精確な配管設計が できていることが確認できる． Experiment 1 では， Z 座標が同じで座標と Y 座標は異なるので，折れ曲がりが 1 
つの配管が設計できている，一方，Experiment 2 では，X, Y, Z 座標が全て異なるので，折れ曲がりが 2 つ配管

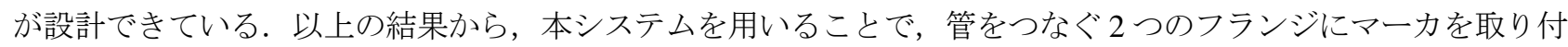
けるだけで, フランジ間の相対位置計測, 自動配管設計, そして, ARによる設計案の確認を行うことが可能で あることを確認した.
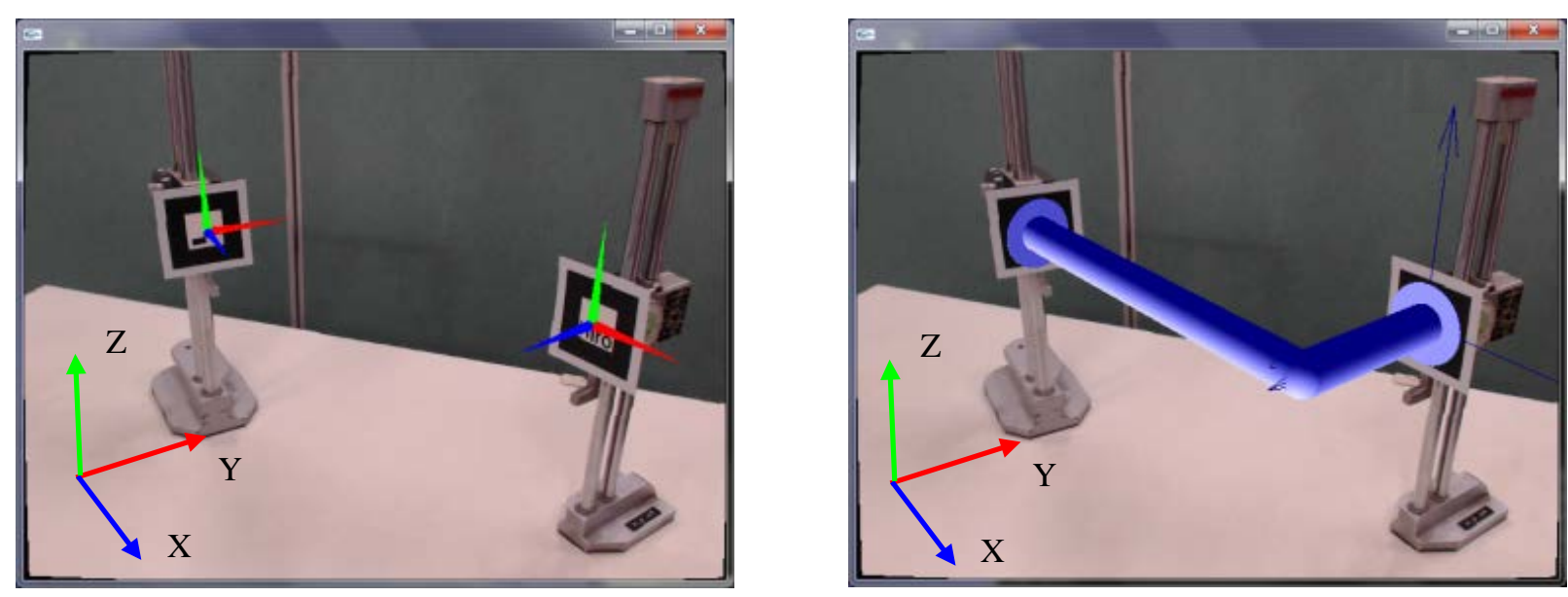

Fig.2 Result of Automatic Piping Design (Experiment 1)
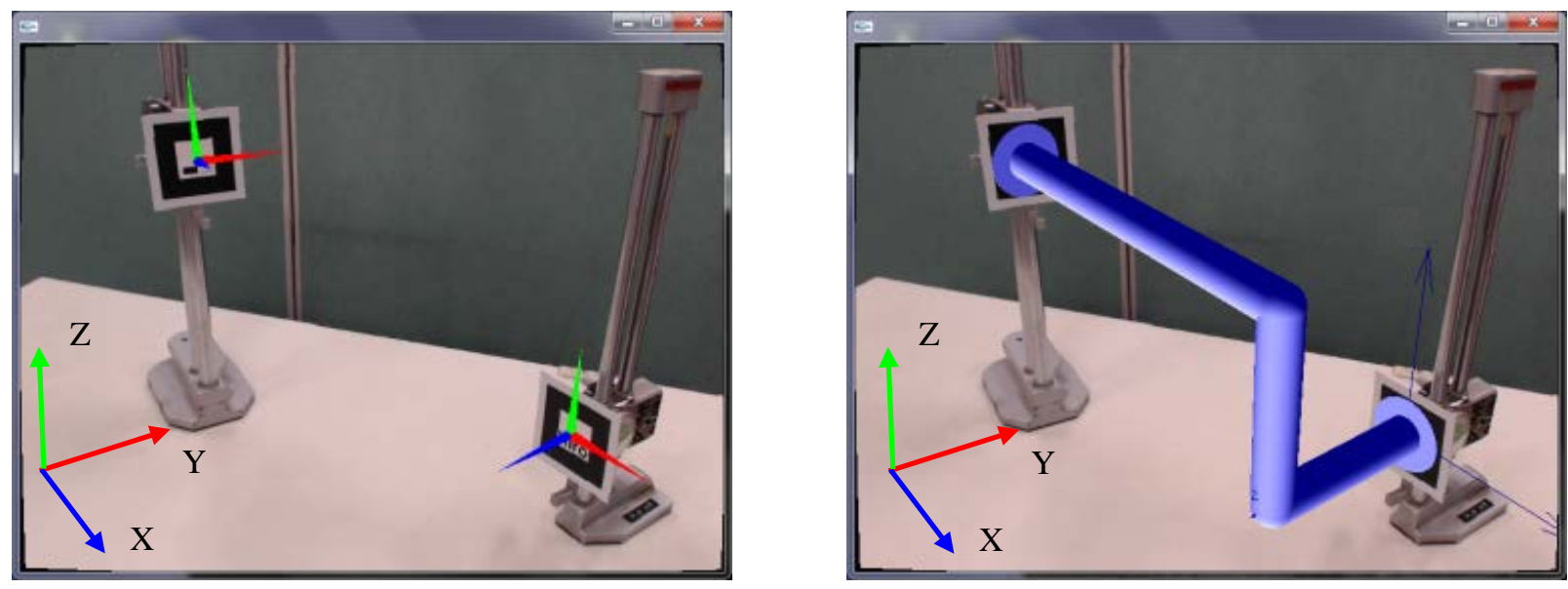

Fig.3 Result of Automatic Piping Design (Experiment 2)

\section{3. 実証実験}

\section{$3 \cdot 1$ 概要}

配管施工支援 AR システムの有用性を検証するために，修繕船の船内において実証実験を行った．対象となる 現場合わせ管は，機関室内のバラストポンプを接続するためのパイプである. 実証実験の対象としたバラストポ ンプと接続するフランジの写真を図 4 の左図に示す. 対象とするフランジは, JIS 規格における溶接フランジで,

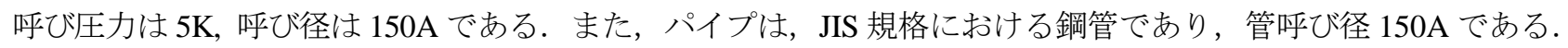
フランジ間の距離は，約 300mm である．実験内容は以下の通りである.

・ 配管施工支援 AR システムを実際に使用し, 位置計測, 自動配管設計, ARによる設計案の表示の 3 つの機 能を修繥船の船内でも利用できることを確認する.

・ 本システムを実際に使用することで，作業現場における操作性等の問題点を抽出する.

・現場の作業員からヒアリングを行い，本システムに関する意見を収集する.

次節に実証実験の結果と得られた考察について述べる. 


\section{$3 \cdot 2$ 実証実験結果及び考察}

対象となる配管は, 機関室内のバラストポンプと接続するための管である (図 4 左図). 製作する配管が取り付 けられる相手側フランジにマーカを取り付け, カメラのついたタブレット PC を通して作業者が見ている様子が 図 5 である．両端の相対位置計測及び配管自動設計が終了し，配管設計案を AR 表示している様子が，図 6 であ る. 図6から，取り付けるべき配管の設計案が AR 表示によって直感的に確認できることが見て取れる. 本来, 以下の機能を完備して配管施工支援 AR アプリは実用上使えるシステムとなるが，本研究での開発時点ではまだ 実現できておらず，今後の開発課題である.

・ 自動設計された配管設計案を実際の空間を背景に AR 的に直感的操作（タッチパネル操作）で修正する機 能.

- 工場での配管製作の参照とするための図面作成機能.

・ ここで作成した配管 3 次元データを設計の CAD データベース等に送信し, 船舶情報の共有化を図る機能.
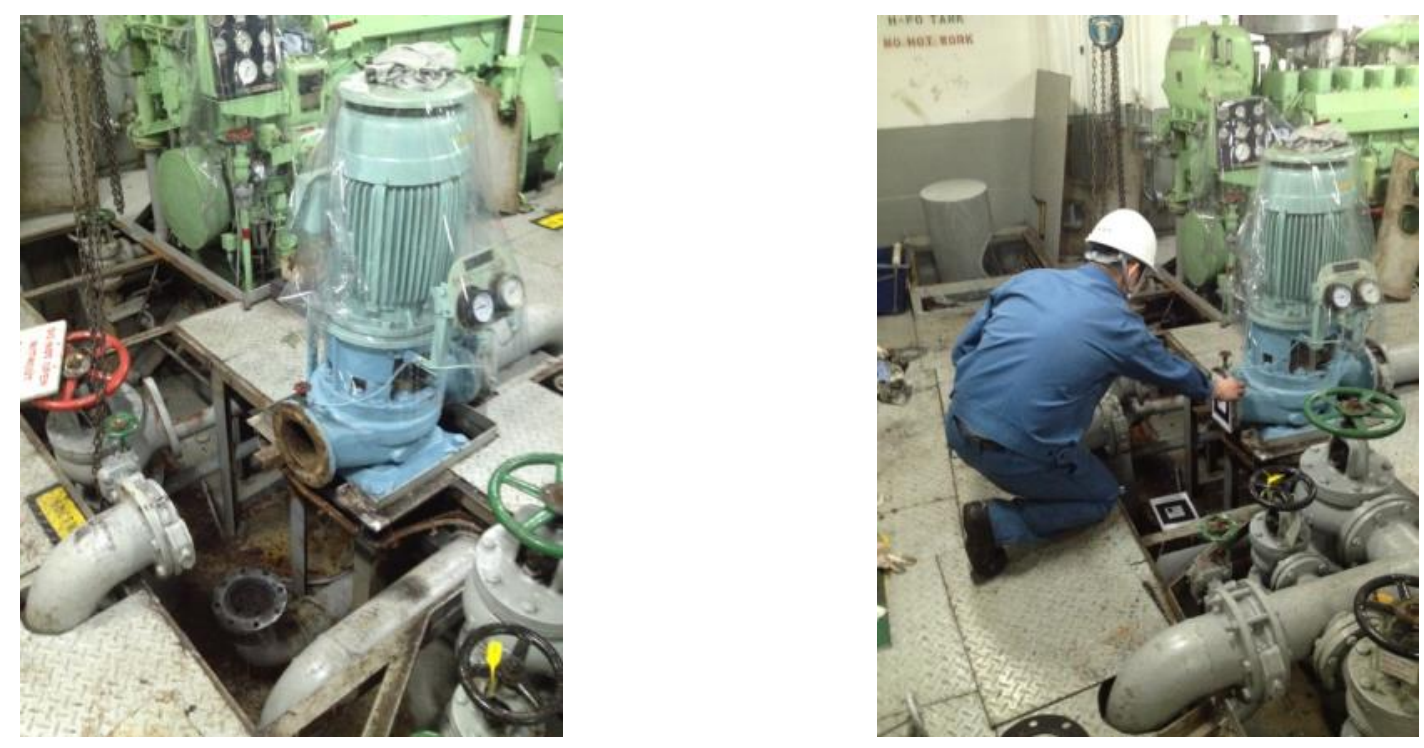

Fig.4 Snapshot of the ballast pump for drawing piping and setting of AR makers.
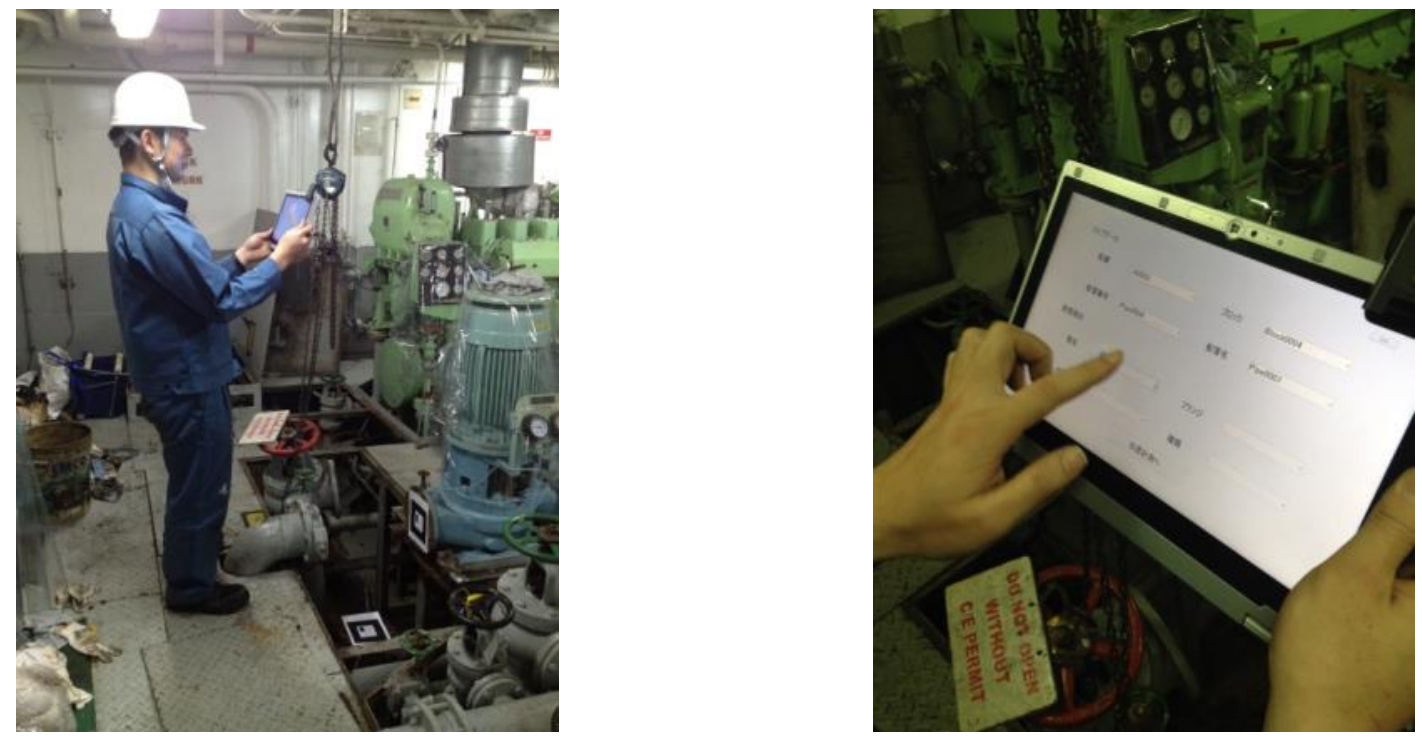

Fig.5 Snapshot of the measurement of the flanges and input of the piping data. 

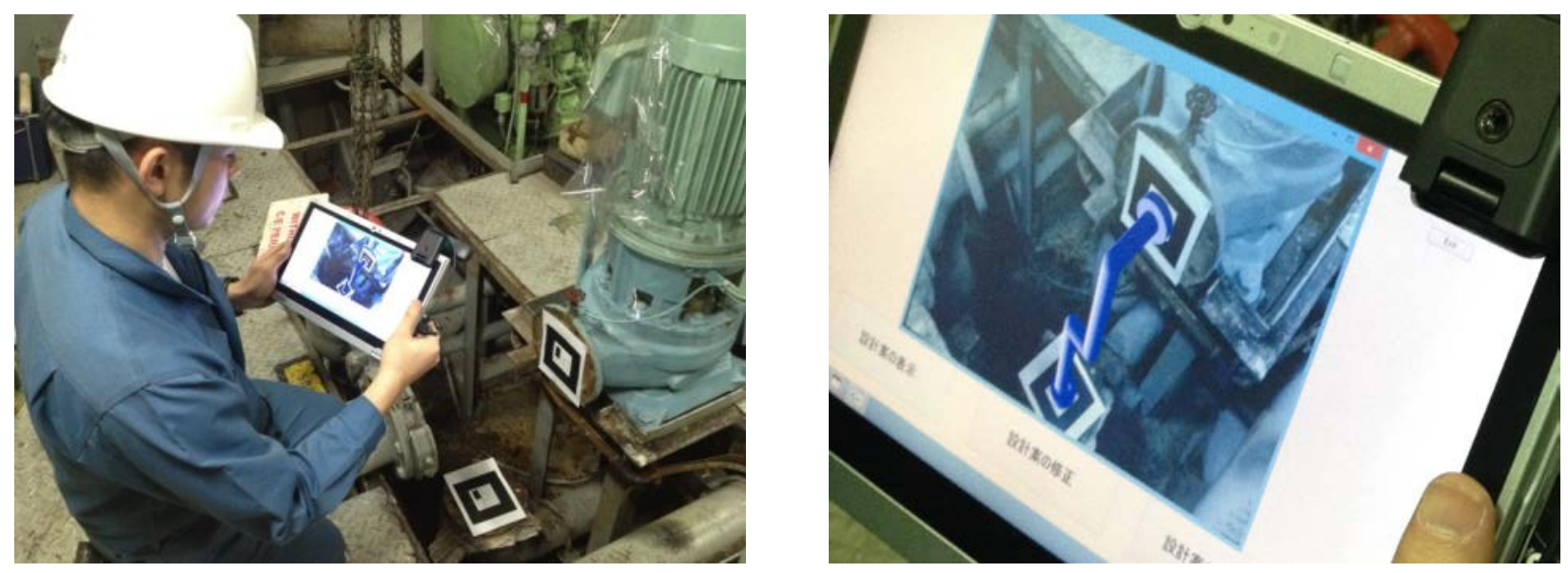

Fig.6 Snapshot of viewing the designed pipe using AR

\section{$3 \cdot 3$ ヒアリングの結果}

実際に使用した結果と作業員からのヒアリングを通して以下の課題点が明らかになった.

(課題 1) 施工対象のパイプ以外にも数多くのパイプやそれらのサポート等の障害物が存在するため, それら を回避した配管設計が必要である.この課題を解決するためには, 障害物を認識する機能を追加して, 自動配管設計で回避する方法と現場で設計案を修正する現場設計機能の追加する方法が考えられる. 前者の案を実現するためには，3 次元深度計測装置を用いて障害物を計測し，その計測データを自動 配管設計ツールに入力することで，障害物を回避した配管設計が可能である．深度計測装置を用いた 形状計測については木村らが既に実施しており，その有用性が確認されている(木村, 2014). 後者につ いては，現場の作業員がタブレット上に表示された配管をタッチパネル操作で動かすことによって， 配管の位置やエルボの数などを考慮して設計案を修正することが可能である．現場での配管設計につ いても進藤らが既にアルゴリズムとアプリケーションの開発を行っている(進藤, 2014). この機能を著 者ら開発したアプリケーションに組み込むことによって，現場での配管設計及び修正が可能になると 考えられる.

（課題 2）障害物によってマーカが隠れる場合があるので，その問題を解決した位置計測方法及びマーカの工 夫が必要である．この問題は，複数のマーカを使用することで解決することが可能である．具体的に は，フランジとフランジとの間の任意の位置にマーカを取り付け，それらのマーカ間の相対位置を計 測していくことで，フランジとフランジの相対位置を計測するという方法である．追加するマーカの 位置はどこでも構わないので, 最初のマーカを片方のフランジのマーカがカメラのフレームに収まる 範囲に取り付け，相対位置を計測する．次のマーカは最初のマーカとカメラのフレームに収まるよう に取り付けて相対位置を計測する．もう片方のフランジのマーカと追加したマーカがフレームに収ま るまでこの操作を繰り返す，そして，最終的に得られたマーカ間の相対位置からフランジとフランジ の相対位置を算出することが可能である.

（課題 3）船内は作業スペースが限られており，カメラとマーカの距離を十分に確保できず，位置計測を行え ない場合がある．このような場合は開発してアプリケーションは使用することができない．しかしな がら，この場合，パイプを配置できる場所も限られ，配管設計の自由度も下がるため，作業員が容易 に配管設計を行うことができると考えられる.

（課題 4）カメラとマーカが離れている場合, マーカの認識精度が下がる場合がある. これについては, 課題 2 の解決策である複数マーカの使用で解決することが可能である．マーカの認識精度が確保できる位置 にマーカを追加していくことで，十分な精度で位置計測を実施することが可能である.

今後, 上の課題点の改善や追加機能の開発を行い，実際の造船所において実用化できる ARアプリケーション を開発する. 特に, ARアプリケーションによる計測精度を定量的に見積もって, 計測精度ごとにどのようなシ 
ーン（新造での先行艤装, 新造での船内艤装, 新造でのブロックの継手にある配管, 修繕での利用等) で利用で きるかの仕様を明確にする必要がある.

\section{$3 \cdot 4$ 有効性について考察}

本節では実証試験の結果をもとに，開発したシステムが実際の造船現場で使用できるか考察を行う。

現場合わせ管の施工で要求される精度はパイプの径や長さによって異なる. 本研究で対象としている現場合わ せ管のパイプの径は 20mm〜150mm, 配管の長さは 1500mm 以内としている. 事前に行ったヒアリングにおいて, この範囲の配管施工で必要とする精度は数ミリオーダーであることを確認している. この範囲であれば, パイプ に外力を加えて曲げることも可能であるため, 問題なくフランジとフランジをつなぎ合わせることができる.

開発したアプリケーションの計測精度については屋内での実験において検証を行っている(白石, 松尾, 2014a). その結果，カメラとマーカの距離が 1000mm〜1500mm 以内であれば数ミリオーダーで計測できることを確認し ている. したがって, 開発したアプリケーションは現場合わせ管の施工で要求される精度を有していると考えら れる．船内の環境では，作業環境が暗くカメラの計測距離が長い場合があるので, 計測精度は落ちると考えられ るが，径が $50 \mathrm{~mm}$ 以下の小径管であれば要求される精度も低いため，小径管の施工において本システムは問題な く利用できると考えられる。

従来，現場合わせ管は，物差しによるフランジ間の位置計測や型取りによる配管設計を実施しており，その作 業に数時間を要していた，一方，本システムでは，パイプを接続する 2 つのフランジにマーカを取り付け，後は タブレット上で自動的に配管設計を行うことができるので, 修正等を行ったとしても 1 時間以内には配管設計を 完了することができる. また, 造船では, ブロックに分けて船を建造するため, 必ずブロック継ぎ手が存在する. そのため, 何百本もの現場合わせ管が存在し，その施工作業に膨大な時間を要している. 本システムによって, その作業時間を半分程度にすることができるので, 船 1 隻の建造において何百時間もの作業短縮につながる.

以上の点から本システムを造船システムで利用することは非常に有効であると考えられる.

\section{4. 結}

\section{$4 \cdot 1$ 本研究のまとめ}

本研究では，著者らが開発した配管施工支援 AR システムの有用性の検証と課題点の抽出するため, 修緗船の 機関室内において実証実験を行った。その結果，マーカが視認できる範囲であれば，現場合わせ管の施工におけ る位置計測, 配管設計, ARによる設計案の投影が可能であることを確認した．また，前述したように本システ ムが使用できない状況も存在することが分かった．今後は，実証実験で抽出された課題点を解決していくととも に，現場の作業員が使い易いシステムになるよう改良を図る予定である.

\section{$4 \cdot 2$ AR 技術の応用}

造船における AR 技術の応用には，以下の 3 つのポイントがある.

（1）工作現場での 3 次元情報の有効活用

（2）工作現場での新しい情報表示

（3）設計／工作の新しい情報のやり取り

(1)に関しては，3 次元 CAD で作成した 3 次元モデルを拡大・縮小・回転するだけでなく，今後は，施工手順 のアニメーション化など，工作現場向けに情報を作成・再加工する取り組みが必要と思われる，つまり，本来 3 次元である製品を 2 次元の図面にダウン・ディメンション化せず， 3 次元の情報のままで工作現場に情報提供す るという「3 次元図面」の発想を普及することである. これには, 現場での表示デバイス導入の他, 3 次元 CAD データなどから施工手順などの情報自体を作成する技術開発の取り組みが必要である.また，3 次元情報の閲覧 については，ARだけでなく，立体映像技術（3 次元ディスプレイ技術，ホログラフィー技術等）も注目されてお り，今後，造船設計・工作でこれらをどのように適用するか，検討を続けていくべきである，将来，ウェアラブ ル端末や電子ペーパ，非接触操作等を用いた NUI（Natural User Interface）の普及に伴い，本質的には，人の理解 容易化，作業の脱技能化，情報の精密化・リアルタイム化・見える化，パーソナライゼーション化につながるも 
のと思われる. 最終的には, 情報を 3 次元的に見るだけでなく, 情報を 3 次元的に操作する技術の造船応用につ いても検討すべきと思われる.

(2)に関しては，AR 技術によって「本来見えないもの」を見ることが実現できる．まさに人の能力の拡張のこ とであり, これによって, 危険を感知したり, 各種の状態量（ブロック重量などの工作情報, 温度などの環境量 等）を定量的に把握することができる，造船を含め，既に人は個人の認識能力を大きく超えた範疇の社会活動を 営んでいる. ICT 技術の援用によって, 複雑な事象の「量的感覚」を身に着ける技術開発の取り組みは今後の新 しい方向性と考える.

(3)に関しては，本報告で紹介した配管施工支援 ARアプリケーションの事例の通り，ARアプリを使って，現 物を見つつ現場にて一種の設計作業をすることができる，これは，「現場設計」の考えで，今後，設計部／工作部 の融合など，造船所における情報のあり方を変える取り組みと見なすことができる．また，造船の場合，工場内 の様々な場所に情報が分散している分散型の情報構造になっている. このような分散型の場合, 情報（データ） を記録・収集することが非常に困難であった．AR 機能を搭載したメガネ型情報端末など，ウェアラブル端末の 導入は，分散型情報向けの記録・収集に適しており，造船所のモニタリング・生産管理の抜本的な改善に大きな 可能性を秘めている.これには, 無選別に収集したデータを有意に識別, 選別, 整理する技術開発が必要である.

以上の通り，AR 技術を含む，新しい ICT 技術は造船生産技術のパラダイムを変えうる可能性を秘めており， 今後, 重点的に研究開発を実施する必要があると思われる.

\section{文献}

安藤悠人, 木村元，エルボおよびベンドを考慮した配管設計アルゴリズム，日本船舶海洋工学会論文集，Vol.15 (2012), pp.219-226.

Ando, Y. and Kimura, H., Automatic pipe routing to avoid air pocket, International Conference on Computer Applications in Shipbuilding, Vol.2 (2013), pp.147-153.

加藤博一, 拡張現実感システム構築ツール ARToolKit の開発, 電子情報通信学会技術研究報告, Vol.101, No.652 (2002), pp.79-86.

木村元, 河内基樹, 複数深度計測デバイスによるデータからの 3D 図面自動生成に関する研究, 日本船舶海洋工 学会講演会論文集 Vol.18 (2014), pp.383-386.

Matsuo, K. and Shiraishi, K., Introduction of AR applications for shop floor in shipbuilding, 13th International Conference on Computer Applications and Information Technology in the Maritime Industries (2014), pp.318-326.

村上睦尚, 岩田知明, 松尾宏平, 穴井陽祐，林原仁志，藤本修平，松岡一祥，船舶産業の熟練した技能を有寸る 作業者の減少に対応した新しい生産システムの実現に必要な基盤技術の開発のための研究-建造効率向上に 資する技能伝承教材とシステムの開発-, 海上技術安全研究所報告, Vol.11, No.3 (2012), pp.179-220.

進藤翔平, 木村元, 安田達也, 現場合わせ管の設計支援システムの開発, 日本船舶海洋工学会講演会論文集 Vol.19 (2014), pp.593-596.

白石耕一郎, 松尾宏平, AR 技術を用いた配管施工支援システムについて, 生産システム部門研究発表講演会 2014, No.14-8 (2014a), pp.41-42.

白石耕一郎, 松尾宏平, 配管の現場合わせを支援する配管施工支援ARシステムの開発, 日本船舶海洋工学会講演 会論文集, Vol.18 (2014b), pp.187-188.

\section{References}

Ando, Y. and Kimura, H., An automatic piping algorithm including elbows and bends, Journal of the Japan Society of Naval Architects and Ocean Engineers, Vol.15 (2012), pp. 219-226 (in Japanese).

Ando, Y. and Kimura, H., Automatic pipe routing to avoid air pocket, International Conference on Computer Applications in Shipbuilding, Vol.2 (2013), pp.147-153.

Kato, K., ARToolKit: Library for vision-based augmented reality, Technical report of IEICE. PRMU, Vol.101, No.652 (2002), pp.79-86 (in Japanese).

Kimura, H. and Kawachi, M., A study of automatic 3D-CAD data generation using data from multiple depth sensors, Conference Proceedings of the Japan Society of Naval Architectures and Ocean Engineers, Vol.18 (2014), pp.383-386 
(in Japanese).

Matsuo, K. and Shiraishi, K., Introduction of AR applications for shop floor in shipbuilding, 13th International Conference on Computer Applications and Information Technology in the Maritime Industries (2014), pp.318-326.

Murakami, C., Iwata, T., Matsuo, K., Anai, Y., Hayashibara, H., Fujimoto, S. and Matsuoka, K., Development of fundamental technology for overcoming decrease of skilled workers on maritime industry : Visual educational skill manuals and working assistant systems for improvement of productivity on shipbuilding, Papers of National Maritime Research Institute, Vol.11, No.3 (2012), pp.179-220 (in Japanese).

Shindo, S., Kimura, H. and Yasuda, T., Development of a design support system for field alignment piping, Conference Proceedings of the Japan Society of Naval Architectures and Ocean Engineers, Vol.19 (2014), pp.593-596 (in Japanese).

Shiraishi, K. and Matsuo, K., On piping installation support system using augmented reality, Manufacturing Systems Division Conference 2014, No.14-8 (2014a), pp.41-42 (in Japanese).

Shiraishi, K. and Matsuo, K., Development of pipework support system using augmented reality for gauging pipes in shipbuilding, Annual Autumn Meeting of JASNAOE 2014 Proceedings, Vol.18 (2014b), pp.187-188 (in Japanese). 